\title{
THOMAS BARLOW, 1845-1945
}

\author{
ADDRESS BY SIR ROBERT HUTCHISON
}

\author{
On the occasion of the Memorial Service
}

\author{
Held at the Hospital for Sick Children, Great Ormond Street, on Wednesday, March 7, 1945
}

We are met here to-day in thankful remembrance of the life and work of Thomas Barlow. A memorial service has already been held for him elsewhere which was largely attended by his many friends both lay and medical, but it is fitting that we should have our own simple service here in the Hospital to which he was so much devoted and where much of his best work was done.

We may look upon it, I think, as a form of family worship and recollection for at this Hospital, above most, all who are associated with it feel themselves to be one of a family. It is difficult to realize that it is 70 years since he whom we have in our thoughts to-day first joined this family when he became Assistant Physician to the Hospital and that he served it faithfully thereafter for a period of nearly 25 years and perhaps my only claim to address you this afternoon is that $I$ had the privilege of acting as his House Physician here almost half a century ago. So much, however, did his life exceed the ordinary human span that a generation and a half have elapsed since his retirement from our staff and to many here present, I dare say, he was known only as the Father of our profession and as a venerated and, latterly at least, almost legendary figure; but we remember with pride that he was essentially a Great Ormond Street man and that to the end of his life the Hospital for Sick Children held a high place in his affections.

The generations rise and pass away and most of us are soon forgotten for, as another great medical Sir Thomas said, "the iniquity of oblivion blindly scattereth her poppy', but those few of whom the memory survives are remembered either for their work or for their character; for what they did or for what they were.

We may feel sure that the name of Thomas Barlow will live on both grounds; he earned a permanent place in medical history by his original work, especially in diseases of children, and through the term 'Barlow's disease', which is used on the Continent, he obtained an eponymous immortality. At the same time in the daily practice of his profession he was completely successful and will long be remembered as perhaps the most popular Consulting Physician of the late Victorian epoch. As Dr. Johnson said of Mead-on the site of whose house we are assembled to-day-' no one ever lived more in the full sunshine of life' and his professional opinion was sought by the highest in the land. But though he 'walked with kings' he never ' lost the common touch' and I well remember his saying to me once when he was at the very height of his fame that he sometimes felt he would like to give it all up and work only amongst poor folk. His skill was only matched by his kindness and sympathy for he was not one who ever lost sight of the 'patient' in the 'case '! He was always ready, too, to extend a helping hand to his less fortunate professional brethren who had fallen by the way, or on whom misfortune had come, and his work for the Royal Medical Benevolent Fund on their behalf is known to all. He was in very truth the Beloved Physician, who did justly, loved mercy and walked humbly, quite unspoilt by success.

No one ever obeyed more faithfully that sentence in the Hippocratic Oath binding on all who practise medicine, which enjoins us to 'Keep holy both the life and the art'. Nor had he any need - for in his case it had already been answered-to offer up the prayer of that great Jewish physician of the 12th century, Maimonides:

-.. Let me be intent on one thing, $O$ Father of Mercy, to be always merciful to thy suffering children. . . . That I may be able to devote myself, body and soul, to thy children who suffer pain.'

May all who serve this Hospital be given grace and strength to follow in his footsteps. 